\title{
Between Monroe Doctrine and Manifest Destiny: Spanish American Travel Narratives of Jacksonian America
}

\author{
Astrid Haas
}

Both description of an outside world and occasion for inner reflections, both representation of an "other" and articulation of notions of the self, travel narratives offer a unique insight into conceptualizations of communities and cultures. Through their depiction of sites and societies of "otherness" for audiences "back home," and through their referring back and forth between the two locations and communities of their concern, travelogues have been particularly formative in constructing notions of ethnic and national identities. Such texts have often partaken in a "civilizing mission" of (post)colonial subjects that seek to legitimize their political or cultural domination by means of asserting especially the national or ethnic differences among visitors and the peoples they visited.

Spanish American travel narratives about the United States have been performing a crucial function in reversing the dominant trajectory of "Western" travelers' routes and gaze - the European or U.S.-American traveling and looking South, East, or West. ${ }^{1}$ In contrast to the rather critical perspective of later narratives, Spanish American travel texts of the Jacksonian era tended to depict the United States as a likely model for their own countries. The present chapter focuses on two Spanish American travelogues about the United States from the 1830s and the way they construct notions of both U.S. and Spanish American national identities: the Mexican politician Lorenzo de Zavala's Viaje a los Estados Unidos del Norte de América (1834) and the Cubanbased Spanish intellectual Ramón de la Sagra's Cinco meses en los Estados-Unidos de la América del Norte (1836). Published around the same time as Alexis de Tocqueville's influential study La démocratie en Amérique (1835), these two works provide different vistas of the United States than the canonical French text, while at the same time they offer critical reflections on Spanish American societies and cultures.

\footnotetext{
${ }^{1}$ I employ the term Spanish American as a referent to Spanish-speaking Latin America(ns) as well as, with regard to Ramón de la Sagra, Spaniards living in and identifying with Latin America. I am well aware of the problems of this as well as related denominators (Chang-Rodríguez 3-5).
} 


\section{Travel Writing and the Construction of Nationhood}

Narrative texts are forms of social practice that actively participate in the shaping of social reality by contributing to larger social discourses through acts of representation (Hall 165). This applies in particular to the construction of "nation" as a key identity category in the West, especially since the nineteenth century, as "literature has traditionally played an important role in the development of a national discourse and the creation of national icons and stereotypes" (Raab 542). More than any other textual genre of the nineteenth century, travelogues were not only thematically concerned with, but also actively participated in, processes of national self-formation via colonial discourses and territorial expansion (Pratt). James Clifford has argued that cultures prominently constitute themselves through practices of travel (including coerced displacements and migrations) and the encounters with other people(s) these engender (3, 24-25). The deep resonance with readers across time and space travel writing has enjoyed rests in particular on the lure of the "authentic" testimony that endows these texts with credibility, on the one hand, and on the function of the travelogue to give meaning to encounters with the strange and different by rendering them in a language familiar to their readers, on the other (Blanton 1-2).

By writing about cultural contacts, travel texts themselves engage in such contacts. As a narrative genre that both results from and discursively (re)constructs cultural contacts, travelogues are particularly apt to fulfill this dual function. According to Mary Louise Pratt, the travelogue's "knowledge" stems in part from the influence of the culture encountered upon the narrator (135-36). The impact of the people being visited on the travelogues of their visitors, however, remains subject to the latter's textual mediation and hence control. The travelers' own identities, previous knowledge, and experiences during the journey crucially inform their perception and subsequent textual representation of the cultural difference they encounter (Blanton 7). The encounter with the cultural other hereby serves as a foil against which traveler-narrators affirm the very culture, identity, and ideology they share with - or seek to promote to - their implied readers (Blanton 3-6, 11-29).

\section{Spanish American Travel Writing of the United States}

Since the colonial era, the Spanish American societal elite had been traveling and residing abroad, mainly to and in Europe and the United States. This process intensified since the first 
former Spanish colonies gained their independence, owing to the new nations' economic expansion, improvements in transportation and communication, and the desire for the modernity upperclass Spanish Americans associated with and sought to learn from the United States and Europe. Struggles over the formation and political direction of the new nation-states as well as the remaining colonies further drove many Spanish American intellectuals and politicians into - at least temporary - exile, a coerced displacement many of them spent on extended journeys through or residences in Europe or the United States (Fey and Racine xii). Often informed by European travel writing about the United States (Thomas 357), the Spanish American travelers to the United States articulated their own national and hemispheric identities through the contrast with the northern neighbor. More strongly than their European counterparts, however, Spanish American travelers used their experiences in the United States as a "look into the mirror" (Suárez Argüello 73,89 ) to critically reflect upon their own societies.

Spanish American travelogues of the United States from the early and mid-nineteenth century are situated at a moment of historic shift from the shared Anglo- and Spanish American experience of coloniality to an unequal relationship between the United States and its southern neighbors, as the United States, herself an independent nation only since 1776, began to claim adjacent French, Spanish, and Mexican territories. The Monroe Doctrine of 1823, initially conceived to refute European influence in the Americas, was soon used to justify United States interventions throughout the Western hemisphere. It was further developed in the concept of "Manifest Destiny," the country's proclaimed moral obligation to expand its territory and influence on the American continent on the grounds of its political and economic advancement and presumed religious, ethnic, and cultural superiority over its southern neighbors. ${ }^{2}$

While these developments in United States politics rendered Spanish Americans and Spanish American travel writing since the 1840s increasingly critical of their northern neighbor, ${ }^{3}$ Spanish American travelogues of the Jacksonian era paint a different picture of the United States. ${ }^{4}$ Following the logic of the Spanish American elites of the period, to which their authors belonged, these texts, while acknowledging the shortcomings of the country, look to the United States as an

2 See Finzsch 211-25, 414-23, 430-47, 473-79. As early as 1786, Thomas Jefferson expressed a U.S. claim to territorial expansion toward the west and south of its borders (Thomson 303).

3 See the studies by Krauze; Thomson; Valdés Ugalde on this development.

4 In a narrow definition of the term (as used in the present chapter), this refers to the time of the presidency of Andrew Jackson (1829-1837). To denote key principles in U.S. politics, economy, and society, the term "Jacksonian Democracy" is often applied to the larger era from 1825-1850 (Finzsch 157-59, 261-64). 
exemplary case of political, social, and economic progress and a model for their own nations to follow, at least to a certain degree (Suárez Argüello 72-73, 78, 103; Thomson 302-03).

\section{Lorenzo de Zavala's Viaje a los Estados Unidos del Norte de América (1834)}

Lorenzo de Zavala (1788-1836) was a Mexican newspaper editor, liberal democratic politician, and writer from the criollo elite. One of the key players in the Mexican independence movement, he subsequently served his country in various political positions. Forced into exile when Centralist conservative forces (re)gained power in Mexico in 1829, Zavala traveled through the United States in 1830. Following his exile in France and return to Mexico, he spent another month in New York in 1833-1834 (Rivera; Suárez Argüello 73-76; Trejo). A prolific political writer, he is known today for his analyses of the Mexican independence movement as well as his account of his journeys to the United States, Viaje a los Estados Unidos del Norte de América [Journey to the United States of North America], first published in Paris in 1834 (Rivera 428-33). Explicitly based on Zavala's travel diaries as well as his readings of various European travelogues (Zavala 1, 5; also Rivera 429; Suárez Argüello 75; Trejo 66), Viaje a los Estados Unidos was written as both autobiography and political guidebook for Mexican public decision-makers (Zavala 1, 101; also Mexal 79). The text comments on the political and economic system, social structure, customs, and manners of United States society. Following U.S.-American political discourse (Rivera 434-35), the narrative largely characterizes the United States as a utopian space and spectacle - a social laboratory for the study of democracy as a political system and a unique "living and persevering example of social Utopia" (Zavala 190). Like other Mexican liberal intellectuals during the 1820s and 1830s, Zavala's main impetus for studying the United States was to assess the possibilities of the country as a possible model for Mexico to follow for her own political, economic, and social advancement, ${ }^{5}$ and his observations and desire to believe in the utopian potential of the United States were crucially informed by his political exile (Mexal 89; Suárez Argüello 91).

Viaje a los Estados Unidos compares the United States to Mexico in an almost overwhelmingly positive way. The text eulogizes the country as being more prodigious than its most famous Old-World predecessors, the ancient Greek and Roman republics (Krauze 32). Zavala

5 While liberals/federalists had triumphed over conservatives/centralists in the formulation of the Mexican Constitution of 1824, many liberal intellectuals, including Zavala, felt soon dissatisfied with the weak executive and the retention of traditional power structures, especially the privileges of the military and the Catholic Church (Valdés Ugalde 580-85; Mexal 82-87, 92; Thomson 305). 
claims that the U.S.-American political system surpasses the classical European democracies, as public opinion is formed here on the basis of a broad public access to information rather than on the skills of political orators, and as it offers its population greater political, social, and economic liberty and equality: "It seems that from the superb cupola [of the Capitol in Washington] freedom and liberation of thought and ideas are announced to humanity, while in that original Capitol in Rome subjection, slavery, and blind obedience were preached" (111; see also 81, 189).

The travelogue attributes the prosperity and progress of the United States to the prevailing work ethic and meritocratic principle of her society. Written in the essentializing manner typical of the genre's comparisons of cultures, a paradigmatic passage argues:

The Mexican is easy going [sic], lazy, intolerant, generous almost to prodigality, vain, belligerent, superstitious, ignorant, and an enemy of all restraint. The North American works, the Mexican has a good time; the first spends less than he has, the second even that which he does not have; the former carries out the most arduous enterprises to their conclusion, the latter abandons them in the early stages [...]. In the United States all men are property owners and tend to increase their fortune: in Mexico the few who have anything are careless with it and fritter it away. ${ }^{6}$

Sadly ironical, Zavala's narrative has internalized the U.S.-American national cultural stereotype of her southern neighbor that the United States began to increasingly put forth to justify her claims to territorial expansion into and socio-economic hegemony over Latin America at the very moment Zavala presented the United States as a model for Mexico (Rivera 436-37).

Zavala's narrative more specifically regards U.S.-American advancement as a direct result of the country's political institutions, which he sees as guaranteeing broad participation in public life and a comparatively equal distribution of wealth. These manifested themselves to Zavala most prominently in the institutions in which public opinion is formed - the popular assemblies on all levels of political life and a free press - as well as in the high degree of literacy, which he positively contrasts with the prevailing political censorship in Mexico (23, 72, 74-76, 81-82, 111, 190; also Rivera 431; Suárez Argüello 90, 94). In a similar vein, Zavala, while scrutinizing the materialism, hypocrisy, and lack of sociability he encounters during his journey to the United

6 Zavala 2-3; see also 38-39, 41-42, 71, 139, 157, 165, 188-90, 192-93; Mexal 93-94; Rivera 436-37; Suárez Argüello 99-100, 103-04. 
States (36, 42, 44, 86, 93, 156-57, 165, 193; also Rivera 438; Suárez Argüello 100), highly praises the relative social and economic equality he sees at work there. Especially with regard to the extreme poverty of the Amerindian communities in Mexico, he argues that even the destitute in the United States have decent food to eat, clothes to wear, and a dwelling to live in. He ascribes their situation to the fact that, in his view, many U.S.-Americans owned their own property as well as were given economic opportunities, regardless of their social class, religious affiliation, or national origin $(29,35-36,39-40,42,50,53,164-65$; also Suárez Argüello 91). Zavala further emphasizes that the United States does not grant legal privileges to a dynastic aristocratic class but rather recognizes a "nobility" of intellect and/or wealth that results from individual talent and achievements (92-94). Only this meritocratic principle of according social privilege, he implies, is truly adequate for a liberal, democratic republic, when he asks, speaking about Mexico: "How can people who recognize entire classes as superior to others because of legal privileges convince one of their sincere and true love of liberty?" (93-94).

Zavala's critique of legal privileges not only targets the upper social strata but also the Catholic Church. While his narrative scrutinizes (past) religious oppression and fanaticism in the United States $(72,190)$, Viaje a los Estados Unidos praises the separation of church and state in the country as superior to the authoritarianism and conservative political entanglements of Mexican State Catholicism. In his travelogue, Zavala marvels at the deep faith of U.S. society, whose being paired with a strong pluralism of creeds and the absence of formal privileges given to any denomination truly embodies the principles of liberty and democracy $(44-45,72-73,127-28,149$, 158, 188-89; also Rivera 432, 437; Suárez Argüello 95-96). In one passage he favorably compares U.S.-American Protestant camp meetings to the Catholic Church in Mexico. While the former in his view create community cohesion and spread the values of temperance and faith among the population, the latter stands out negatively for its pomp, lack of concern for its believers, corruption of popular morals, and exploitation of its worldly power as state religion (32-35; also Suárez Argüello 96). The church, Zavala claims, has turned Mexico's indigenous population into a "horde of idolaters who come to deliver into the hands of lazy friars the fruit of their year's work to enrich them, while they, their women and children have no clothing, not even a bed" (35).

The single point in which Viaje a los Estados Unidos explicitly places Catholicism above other denominations concerns the role of organized religion in U.S.-American race relations. In New Orleans, Zavala observes that 
in a Catholic church the black and the white, the slave and his master, the noble and the common man kneel before the same altar, and there is a temporary unawareness of all human distinction [...]. In the Protestant churches such is not the case. All people of color are excluded or separated in one corner by bars or railings, so that even in that moment [of religious worship] they have to feel their degraded condition. (16-17)

Even though Zavala himself endorsed the plan circulating in the United States to (re)locate African Americans to Liberia (141-42; also Suárez Argüello 97), his travelogue fiercely denounces the enslavement of and racial discrimination against the black population as an attack on human rights that is detrimental not only to the victims but also to U.S.-American civilization. Employing a reference easily comprehensible to readers in Europe and the Americas, the text proclaims: "The colored people [...] are the Jews of North America" (90; also 20-23, 27, 30, 90-91, 14243; Rivera 438; Suárez Argüello 97-98). Zavala's Viaje especially scrutinizes the existence of slavery and racial discrimination in a country that proclaims freedom and democracy for itself as well as for other nations. Here is, finally, a field in which Mexico appears as being more enlightened than the United States: going from his country to a slaveholding state of the United States, the narrative argues, the Mexican traveler "experience[s] a pleasant memory for those who have abolished this degrading traffic and caused to disappear among us the vestiges of so humiliating a condition of the human race" (20; also Rivera 438; Suárez Argüello 97). Zavala immediately adds that it was Mexico's liberal president Vicente Guerrero who outlawed the "peculiar institution" in his country in $1829(20)$.

In choosing the format of the first-person travel account interspersed with third-person comments on political and social institutions of the United States, Zavala claims the "innocent" and incomplete perspective of the tourist and the authority of the learned political observer at the same time. As it adopts the tourist's homogenizing gaze usually directed at other cultures for his description of the United States as well as Mexico, Viaje a los Estados Unidos creates a certain distance to either nation and thus offers a critical comparison of both (Mexal 80-81, 93-94, 10003). While he extensively cites from travelogues written by European visitors to the United States, Zavala unmasks and critiques their Eurocentric perspective and often-implied imperialist mission (Rivera 433) in the way he questions the adequacy and fairness of their comparisons between the Old and the New World: 
The strangest thing is that in order to measure the civilization of Cincinnati one should speak of the society of London and Paris. It is not surprising thus to find the Catholic cathedral small and insignificant when compared with Notre Dame of Paris, and the same with the Protestant church when compared with St. Paul's of London. (Zavala 41-42)

Despite its scrutiny of U.S.-American racial discrimination, materialism, and flawed social interactions, Zavala's Viaje urges Mexican society to remodel itself in the mold of their northern neighbors (3). However, in contrast to Enrique Krauze's (33) and Ana Rosa Suárez Argüello’s (103) readings, the narrative does not advocate Mexico's complete adoption of the U.S.American model. On the contrary, the Mexican traveler qualifies his general praise of the United States by admitting that "we [Mexicans] are not always sincere in our flattery or our compliments" (42-43; also Mexal 80-81), and he explicitly criticizes Mexico for having "copied [U.S. political institutions] so servilely" (Zavala 1; also Mexal 79-81, 103; Rivera 429-30, 438-40), because the American model "was sublime but not to be imitated" (Zavala 193; also Mexal 103; Rivera 438-40). He ends his narrative, though, with a prediction that, no matter what Mexicans think about the United States, "the American system will obtain a complete though bloody victory” (195; also Suárez Argüello 78; Thomson 305).

\section{Ramón de la Sagra's Cinco meses en los Estados-Unidos de la América del Norte (1836)}

Ramón de la Sagra (1798-1871) was a Spanish naturalist, historian, politician, and social reformer. Since 1823 he held the Chair in Natural History at the University of Havana and was soon also appointed director of its Botanical Garden. Feeling estranged from Cuba but no longer at home in Spain either, he went on a five-month journey to the United States in 1835 before settling in Paris and returning to Spain in the late 1830s (García-Montón 193, 202; Quirós Linares 229-30, 237; Townsend 43-45, 47). While his best-known writings include studies on Cuban geography, nature, economy, and society as well as social and economic analyses of Spain, he also wrote several travel accounts, among them Cinco meses en los Estados-Unidos de la América del Norte [Five Months in the United States of North America], which first appeared in Paris in 1836 (Quirós Linares; Rodríguez Caamaño; Townsend). The narrative further represents the first testimony of the young United States published in Spain (García-Montón 193). As Francisco Quirós Linares points out, the U.S.-American journey marked la Sagra's turn to prominently addressing social issues in his work (237; see also la Sagra 97). 
In contrast to Viaje a los Estados Unidos, la Sagra's narrative retains the character of the travel diary and the claim to the immediacy of the observation and "truth" of the personal testimony this format entails (la Sagra ix-xi). The text was published with the intention to provide Spanish and Latin American readers with useful information on the United States (xi-xiii, xxivxxvi, 95-97; also Quirós Linares 237); Cinco meses en los Estados-Unidos joins Zavala's Viaje in articulating a strong admiration for U.S.-American society and its social, political, and economic progress. Strikingly reminiscent of the Mexican's praise of the United States and implied critique of the lack of freedom elsewhere, la Sagra, in an exemplary scene of his narrative, muses on the impact of liberty on the behavior of the lower classes:

In Europe I saw the miserable skilled worker numb himself on Sundays [...] to forget that the next day he would not have a day's pay that would feed his large family [...], and I look at the calm and quiet free men of the United States. The more I see of this society, the more I admire it and the more surprised I am. [...] [H]ow wrong are those in Europe who think that liberty must be associated with disorder, immorality and irreligion! ${ }^{7}$

Unlike Zavala's Viaje, Cinco meses en los Estados-Unidos does not emphasize the political system and structures of the United States, though. In line with its author's interests, it dwells at length on U.S.-American science and technology, agriculture and industry, religious practices, as well as charitable, educational, and corrective institutions - mainly, schools and colleges, hospitals and lunatic asylums, poorhouses, prisons, and correctional facilities for juvenile delinquents. Although the narrative points out institutional deficiencies (68-69, 90-91, 190-94, 425), it particularly recommends the strong educational and financial investment these institutions make in their clientele as a model for other nations to imitate. This commitment, the text argues, shows the exemplary dedication of U.S. society to take care of the young, the sick, the poor, and the deviant (xviii-xix, 11-12; 192-95; also García-Montón; Quirós Linares 237-39; Townsend 4849, 51-52) that distinguish the nation: "The examination of the charitable institutions made me realize their absence in Spain" (12, my translation), la Sagra sums up.

Highly critical of the Spanish prison system, which paid greater attention to expiation and intimidation than to crime prevention and the moral improvement of prisoners (Rodríguez Caamaño 266-68), the Spanish scholar pays special attention to the correctional facilities he vis-

7 la Sagra 116, my translation; italics original. See also 34, 49; Townsend 42, 49. 
ited in the United States. Cinco meses en los Estados-Unidos praises the way the penitentiaries spawn industry, piety, and obedience among prisoners through a regime of silence and manual labor $(50-52,62-70,117-23,150-52,205-16,284-94,323-26,337-43,402-05,425-34)$ as a model for Europe, and the text applauds the balance of education and work provided in the institutions for juvenile delinquents as a way of equipping these often poor and uneducated youths for a law-abiding adult life (12-19, 76-80, 326-32).

Education and the access to it for all walks of life in fact represent a core element in la Sagra's concept of progressive society. His Cinco meses en los Estados-Unidos explicitly counters the critique that "the prisons of the United States find themselves full of the criminals who have received the criminal poison of education in schools, colleges, and universities" (408, my translation; italics original), arguing that the majority of delinquents lacks a good education and that the "easy entrance" of vices, corruption, and poverty into the cities are to be blamed for higher urban crime rates (408-10). Time and again, the narrative not only points out the broad curriculum of the U.S.-American schools and universities but also notes how the tuition of the wealthier students funds the schooling of the poorer ones $(90-92,104,107,112-13,148-49$, $162-63,184-99,218-25,228-29,351-53,369-71,385-86,412-18)$ as well as assesses the measures that are taken to provide quality schooling to the disabled (24-32, 167-70, 364-68, 396-401). This critical appraisal of the U.S.-American educational and corrective system as well as his willingness to meet the residents of almshouses, asylums, and correctional facilities set la Sagra tellingly apart from many European travelers to the United States, who tended to share the Spanish notion of social stratification as well as of crime and punishment (Townsend 49-50).

As moral education plays a key role in the Spanish scholar's concept of societal reform (xvii-xxi; also Rodríguez Caamaño 269-70) that he sees partially realized in the United States and seeks to inspire in Spain, as well, Cinco meses en los Estados-Unidos honors the piety of U.S.-American society, from the observance of Sunday and the institution of Sunday school (45$48,92-95,333-34,368-69,419)$ to the religiously motivated temperance movement, whose radicalism it defends against its European critics (296-303). La Sagra's rejection of drinking further made him partially blame the poor in the United States for their condition. In contrast to the destitute of Spain, he argues, "many of them [in the United States] are robust men whose vice rather than a lack of work is responsible for bringing them to this asylum" (128, trans. in Townsend 50; see also la Sagra 319-20). 
Later in his life, la Sagra's writings about the United States would become more critical, as he especially denounced slavery and racial discrimination in the entire American hemisphere and advocated their abolition (Rodríguez Caamaño 269; Quirós Linares 238). In his U.S.American travelogue, however, he addresses these subjects only briefly. He justifies his not traveling further south in the United States than Baltimore by claiming that the institution of slavery there would invoke "melancholic" reminiscences of Cuba (97; also Townsend 50), and it is rather in passing that Cinco meses en los Estados-Unidos complains about the racial discrimination in education and the workplace African Americans encounter in both slaveholding and free states (18-19, 105, 153-55, 343-45; also Townsend 50). As Camilla Townsend observes, la Sagra possibly wanted to avoid comparisons with his own implication in these practices during his stay in Cuba in the $1820 s .^{8}$ In line with his emphasis on education but politically problematic nonetheless, la Sagra argues in his U.S.-American travel narrative for a cautious liberation of slaves. While philanthropists should strive to improve the lot of slaves, he writes, both in the United States and Cuba free blacks were the most morally depraved class: "Liberty is the most disastrous gift that could happen to the unhappy African who has not received any education," and without education, the decree of emancipation sure to come would be a "decree of calamities opening up before the unhappy, whose fate it attempts to improve, an abyss of crimes and disgrace" (153-54, my translation).

Like Zavala's travelogue, la Sagra's journey account, while disclaiming to present a fortunate United States as a model to an unfortunate Spain (xii), does precisely that: it demonstrates the benefits of U.S. political liberty, economic opportunity, and social equality in order to inspire reforms in his native country - including its remaining colonies such as Cuba - and the European continent as a whole (xii-xxvi, 89, 181-82, 242-44, 251-52, 376, 436; also García-Montón 193; Townsend 42, 46, 48). Echoing his Mexican contemporary, la Sagra eulogizes the widespread prosperity $(1-2,242-44,284)$ as well as the absence of a dynastic aristocracy (62-63) in the United States, and he even describes the Capitol in Washington, DC as a "sanctuary of liberty and bulwark of American independence" (130, my translation). He crucially deviates from Zavala, however, in not calling for substantial political changes but for the moral reformation of European civilizations (xvi, xxi-xxiii).

8 She points out that, while la Sagra in theory opposed slavery, in practice he "frequently hurt the slaves" (Townsend 45; also 46-47) he had contact with in Cuba. 


\section{Conclusion}

Lorenzo de Zavala's and Ramón de la Sagra's texts represent two among a number of Spanish and Latin American travel accounts of the United States in the early nineteenth century which counter the European and North American gaze that dominates discourses about the Iberoamerican world. In the way Zavala's Viaje a los Estados Unidos and la Sagra's Cinco meses en los Estados-Unidos promote Mexico's and Europe's (especially Spain's) critical inspiration by, yet not blind adoption of, United States political liberty, institutional social equality and care, economic opportunities, and work ethic, the two travelogues engage in an act of transculturation (Mexal 101). According to Mary Louis Pratt, transculturation

describe[s] how subordinated or marginal groups select and invent from materials transmitted to them by a dominant [...] culture. While subjugated people cannot readily control what emanates from the dominant culture, they do determine to varying extents what they absorb into their own, and what they use it for. (6)

In their transcultural articulation of a vision of Spanish America along with their critical observation of the United States, Zavala's and la Sagra's texts moreover parallel and crucially complement the well-known analysis of Jacksonian U.S.-America provided in Alexis de Tocqueville's famous study Democracy in America (1835). Both travelogues share the French observer's attribution of United States prosperity and progress to her offering a comparably high degree of political liberty and economic equality. ${ }^{9}$ Yet, the Spanish American narratives integrate a political critique that is absent in the French nobleman's writing: Zavala's lament on Mexican backwardness scrutinizes the Spanish colonial heritage from the perspective of a Latin American-born liberal political elite. La Sagra's concern with an egalitarian social policy, manifest in reformoriented educational and correctional institutions, challenges the rigid social class system and pathologization of the lower classes prevalent among European societies and their remaining American colonies like Cuba. Tocqueville's fear that democracy might lead to a tyranny of the masses over a more "suitable" political class, while it might have been shared by either Zavala, or la Sagra, or both, is strikingly absent in their respective viajes. Despite the shortcomings of the two writers' observations and conclusions, their travelogues offer valuable insights into the social

9 See Rivera 429; Rodríguez Caamaño 265; Townsend 45. On Tocqueville's perception of Jacksonian America see Wilentz. 
constructions of U.S.-American, Mexican, and Spanish nationhood in a time of political shift from shared New World coloniality to an era of imperialism that would divide the hemisphere.

\section{References}

Blanton, Casey. Travel Writing: The Self and the World. New York: Routledge, 2002. Print.

Chang-Rodríguez, Eugenio. Latinoamérica: Su civilización y su cultura. $4^{\text {th }}$ ed. Boston: Thomson Heinle, 2008. Print.

Clifford, James. Routes: Travel and Translation in the Late Twentieth Century. Cambridge, MA: Harvard UP, 1997. Print.

Fey, Ingrid E. and Karen Racine. Introduction: National Identity Formation in an International Context. Strange Pilgrimages: Exile, Travel, and National Identity in Latin America 1800-1900s. Ed. Ingrid E. Fey and Karen Racine. Wilmington: Scholarly Resources, 2000. xi-xix. Print.

Finzsch, Norbert. Konsolidierung und Dissens: Nordamerika von 1800 bis 1865. Münster: Lit, 2005. Print.

García-Montón, Isabel. "Retratos costumbristas de Ramón de la Sagra: La mujer estadounidense del siglo XIX, 1835.” Revista Complutense de Historia de América 24 (1998): 193-202. Print.

Hall, Stuart. "New Ethnicities.” Black British Cultural Studies: A Reader. Ed. Houston A. Baker Jr., Manthia Diawara, and Ruth H. Lindeborg. Chicago: U of Chicago P, 1996. 163-72. Print.

Krauze, Enrique. "Mirándolos a ellos: Actitudes mexicanos frente a Estados Unidos." Letras libres (June 2007): 32-40. Print.

Mexal, Stephen J. "The Logic of Liberalism: Lorenzo de Zavala's Transcultural Politics." MELUS 32.2 (2007): 79-106. Print.

Pratt, Mary Louise. Imperial Eyes: Travel Writing and Transculturation. London: Routledge, 1992. Print.

Quirós Linares, Francisco. "Ramón de la Sagra (1798-1871)." ERIA: Revista Cuatromestral de Geografía 26 (1991): 229-60. Print.

Raab, Josef. "Los Gringos: Latin American Literary Views of the U.S.A.” Negotiations of America's National Identity. Vol. 2. Ed. Roland Hagenbüchle and Josef Raab. Tübingen: Stauffenburg, 2000. 538-70. Print.

Rivera, John-Michael. "“A Complete though Bloody Victory': Lorenzo de Zavala and the Transnational Paradoxes of Sovereignty." American Literary History 18.3 (2006): 427-45. Print.

Rodríguez Caamaño. "Ramón de la Sagra, pionero de la sociología en España." REIS: Revista Española de Investigaciones Sociológicas 88 (1999): 261-71. Print. 
Sagra, Ramón de la. Cinco meses en los Estados-Unidos de la América del Norte desde el 20 de abril al 23 de septiembre de 1835: Diario de viaje. Paris: Renouard, 1836. Print.

Suárez Argüello, Ana Rosa. "Imaginar a la patria en la distancia: Cuatro viajeros mexicanos en Estados Unidos a fines de la primera república federal." La construcción del discurso nacional en México: Un anhelo persistente. Ed. Nicole Giron. Mexico City: Instituto Mora, 2007. 71-107. Print.

Thomas, Jack Ray. "Latin American Views of United States Politics in the Nineteenth Century." Journal of the Early Republic 12.3 (1991): 357-80. Print.

Thomson, Guy. "Mexican Liberals and the Uses of the United States, 1829-1910." Americanisms: Discourses of Exception, Exclusion, Exchange. Ed. Michael Steppat. Heidelberg: Winter, 2009. 301-16. Print.

Tocqueville, Alexis de. Democracy in America: An Annotated Text, Backgrounds, Interpretations. 1835. Ed. Isaac Kramnick. Trans. Henry Reeve. New York: Norton, 2007. 1-617. Print.

Townsend, Camilla. “"The More I See, the More Surprised I Am': Ramón de la Sagra, Baltimore, and the Concepts of Race and Poverty." Strange Pilgrimages: Exile, Travel, and National Identity in Latin America, 1800-1990s. Ed. Ingrid E. Fey and Karen Racine. Wilmington: Scholarly Resources, 2000. 41-57. Print.

Trejo, Evelia. "Lorenzo de Zavala: Personaje de la historia y narrador de historias." La república de las letras: Asomos a la cultura escrita del México decimonónico. Vol. 3: Galería de escritores. Ed. Belem Clark de Lara and Elisa Speckman Guerra. Mexico City: UNAM, 2005. 53-66. Print.

Valdés Ugalde, Francisco. "Janus and the Modern Colossus: Perceptions of the United States in the Building of the Mexican Nation." Journal of American History 86.2 (1999): 568-600. Print.

Wilentz, Sean. "Many Democracies: On Tocqueville and Jacksonian America." 1988. Democracy in America: An Annotated Text, Backgrounds, Interpretations. Ed. Isaac Kramnick. New York: Norton, 2007. 809-25. Print.

Zavala, Lorenzo de. Journey to the United States of North America [Viaje a los Estados Unidos del Norte de América]. 1834. Trans. Wallace Woolsey. Ed. and introd. John-Michel Rivera. Houston: Arte Público, 2005. Print. 